\title{
Pregnancy Rate in Ewes Injected with Zinc Oxide during an Estrus Synchronization Protocol
}

\author{
Corrales-Arévalo, Héctor H. ${ }^{1}$; Rodríguez-de Lara, Raymundo ${ }^{2}$; Hernández-Aquino, Saul ${ }^{1}$; \\ Avelar-Lozano, Ernesto ${ }^{1}$; González-Maldonado, Juan ${ }^{1^{*}}$ \\ ${ }^{1}$ Universidad Autónoma de Baja California. Instituto de Ciencias Agrícolas. Ejido Nuevo León, Mexicali, Baja \\ California, México. C. P. 21705. \\ ${ }^{2}$ Universidad Autónoma Chapingo. Posgrado en Producción Animal. Chapingo, Texcoco, Estado de México, \\ México. C. P. 56230. \\ *Corresponding author: jugomauabc@gmail.com
}

\begin{abstract}
Objective: To measure the effect of zinc injection, during an estrus synchronization protocol, on pregnancy rate in sheep from Valle de Mexicali.

Design/Methodology/Approach: The experimental units were 157 ewes, which were allocated in five farms (F): F1 ( $\mathrm{n}=19), \mathrm{F} 2(\mathrm{n}=27), \mathrm{F} 3(\mathrm{n}=20), \mathrm{F} 4(\mathrm{n}=71)$, and F5 $(\mathrm{n}=21)$. In each farm, the ewes were randomly assigned to one of three treatments: control, z-100 and z-200. The ewes from control groups were subcutaneously injected with $4 \mathrm{~mL}$ of olive oil as placebo. The ewes from groups z-100 and z-200 were subcutaneously injected with 100 and $200 \mathrm{mg}$ of zinc oxide. The response variables were the preovulatory diameter of the largest follicle and pregnancy rate.

Results: The differences between experimental groups in diameter of the largest preovulatory follicle and pregnancy rates were not significant $(p>0.05)$.

Study Limitations/Implications: The ewe's reproductive response to zinc injection might be affected by the animal mineral status, it is recommended to carry on supplementation based on mineral blood concentrations.

Findings/Conclusions: The subcutaneous injection with 100 or $200 \mathrm{mg}$ of zinc oxide did not affect the size of the largest preovulatory follicle and pregnancy rate in ewes.
\end{abstract}

Keywords: Minerals, reproduction, sheep.

Citation: Corrales-Arévalo, Héctor H., Rodríguez-de Lara, Raymundo, Hernández-Aquino, Saul, Avelar-Lozano, Ernesto, \& González-Maldonado, Juan. (2021). Pregnancy Rate in Ewes Injected with Zinc Oxide during an Estrus Synchronization Protocol. Agro Productividad, 14(\#). https://doi. org/10.32854/agrop.v14i6.1948

Editor in Chief: Dr. Jorge Cadena Iñiguez Estimated publication date: July 2021

This work is licensed under a Creative Commons Attribution-NonCommercial 4.0 International license

\section{INTRODUCTION}

The increasing world population and demand for foods of animal origin (Turk, 2016)urbanization and rising incomes are driving greater demand for animal source food in most parts of the world but especially in developing countries. The United Nations Food and Agriculture Organization (UN-FAO makes it necessary to apply strategies in livestock production systems to improve their productivity. In Mexico, sheep production systems are diversified, regarding their technological advance and the breeds used to produce mutton (Partida de la Peña et al., 2017). There are regions such as Valle de Mexicali where sheep production is considered as a subsistence activity, with a low degree of technification (Martínez-Partida et al., 2011). Therefore, there is a need to manage and promote the development of this activity through research studies.

The profitability of sheep production systems can be improved by applying reproductive biotechnologies and nutritional strategies (Gifford \& Gifford, 2013)such as supplying specific nutrients during the occurrence of relevant reproductive events (Delgadillo \& Martin, 2015). The list of these nutrients includes zinc and other trace 
minerals, which are essential for a variety of physiological functions in the animal (López-Alonso, 2012).

Zinc is an essential mineral to sustain life and one of the most abundant trace minerals inside the animal's organism, but its endogenous storage is low and it must be provided to animals by feed or mineral supplementation (Mir et al., 2020; Swain et al., 2016). In the organism, zinc participates as enzymatic cofactor, regulates cell growth, immunity and reproductive function in mammals (Hill \& Shannon, 2019; Nasiadek et al., 2020) whereas zinc body deficiency causes low productive (Masters et al., 1985) and reproductive performance (Tian \& Diaz, 2012; Tian et al., 2014). Zinc can be administrated to animals orally or by injection. The oral administration of zinc has been effective in improving the reproductive performance in ewes (Monem \& ElShahat, 2011) and goats (Kundu et al., 2014), while a similar effect of zinc injection has been observed in cows (Anchordoquy et al., 2019). The latter is considered as more effective in increasing endogenous zinc concentrations in sheep (Lamand et al., 1983). However, we are unaware of the effects of zinc injection on reproductive variables in sheep.

Therefore, the objective of this study was to measure reproductive variables in ewes injected with zinc, during an estrus synchronization protocol, in Valle de Mexicali.

\section{MATERIALS AND METHODS}

\section{Location}

The study was undertaken in five sheep farms located in Valle de Mexicali during the increasing photoperiod season (March-April). The climate in the region is dry arid (BWh), the average rainfall is $85 \mathrm{~mm}$ and the temperature range throughout the year is 0 to $52^{\circ} \mathrm{C}$ (Garcia, 1988). The animals were managed following the Canadian Council on Animal Care guidelines (CCAC, 2009).

\section{Animals and experimental design}

The experimental units were 157 crossbred ewes (Dorper $\times$ Pelibuer $\times$ Katahdin) with at least one lambing and non-lactating. The ewes were distributed in five different sheep farms (F): F1 (n=19), F2 (n=27), F3 ( $=20), F 4(n=71)$, and F5 $(n=21)$. In each farm, the ewes were randomly assigned to one of three treatments: Control (0 $\mathrm{mg}$ of zinc oxide), z-100 (100 mg) and z-200 (200 mg). The zinc oxide (Zinc Óxido, Jalmek) was dissolved in $4 \mathrm{~mL}$ of olive oil and subcutaneously injected to ewes in z-100 and z-200 treatments on day nine of the estrus synchronization protocol (day 0 is the day of intravaginal device (CIDR ${ }^{\circledR}$ ovis, Zoetis) insertion). The number of ewes assigned to each treatment within each farm was as follows: Control: 6, 9, 7, 24 and 7; z-100: 6, 9, 6, 24 and 7; z-200: 7, 9, 6, 23 and 7; for F1 to F5, respectively.

\section{Animal nutrition}

The ewes in $\mathrm{F} 1$ were fed with $2 \mathrm{~kg}$ day $^{-1}$ of a total mixed ratio (48\% alfalfa, 28.84\% Sudan silage and $23.07 \%$ oat straw as feed). The ewes in F2 to F4 were fed ad libitum with 
mixed forage hay (Cynodon dactylon, Echinochloa colona, Echinochloa crus-galli, Sorghum halepense and Medicago sativa). The ewes in F5 had free access to Lolium multiflorum Lam pastures during the entire experimental period. The ewes in the five farms did not receive any mineral supplementation before, during or after the experimental period.

\section{Reproductive management}

The estrus cycle of the ewes was synchronized by intravaginal CIDR insertion for 12 days. The ewes were injected with 350 IU of equine chorionic gonadotropin (eCG, Novormon ${ }^{\circledR} 5000$, Virbac) at day 10 of the estrus synchronization protocol. The intravaginal device was removed at day 12 and the ewes were injected with $12.5 \mathrm{mg}$ of dinoprost (Lutayse ${ }^{\oplus}$, Zoetis). The ewes were inseminated 28-30 h after CIDR removal by cervical insemination method. The semen was provided by the same ram at all times. The semen was collected by artificial vagina just before the artificial insemination; its concentration was determined by Neubauer chamber and diluted with a commerncial medium (Trilady $\left.{ }^{\circledR}\right)$ to the desired concentration $\left(300 \times 10^{6}\right.$ sperm cells $\left.\mathrm{mL}^{-1}\right)$. The diluted semen was placed in a plastic tube surrounded by ice during artificial insemination.

\section{Response variables}

The response variables to the zinc oxide injection were the diameter of the largest preovulatory follicle before insemination and the pregnancy rate. The diameter of the largest preovulatory follicle was measured in five ewes from each experimental group in every farm by transrectal ultrasonography (Handscan V8, Sunway Medical). The two ovaries were observed and the position of the largest preovulatory follicle was recorded. The follicle diameter was calculated by the average of the horizontal and vertical measurements of the largest follicle. The pregnancy diagnose was carried out by transrectal ultrasonography between 30-35 days after artificial insemination.

\section{Statistical analysis}

The residual normality for the diameter of the largest preovulatory follicle variable was tested by the Saphiro-Wilk test. The data from this variable was analyzed using ANOVA and considering the farms as blocks. The means comparison was carried out by Tukey's test. The pregnancy rate was analyzed by Fisher's exact test. However, the data for pregnancy rate from $\mathrm{F} 5$ were not considered in the statistical analysis because there was an accidental loss of the semen sample and a lower dose of sperm $\left(100 \times 10^{6}\right.$ sperm cells) was used to inseminate the ewes. A value of $p \leq 0.05$ was considered as significant. The SAS University Edition statistical package was used at all times.

\section{RESULTS AND DISCUSSION}

Mineral supplementation is essential to sustain adequate animal reproductive activity (López-Alonso, 2012). The minerals can be supplied to animals in feed or by injection. There is evidence that pregnancy rate in ewes is increased by multiple injections of selenium and vitamin E during a synchronized estrus protocol (Awawdeh 
et al., 2019). Similarly, oral supplementation of zinc is effective to improve pregnancy rate (Ali et al., 1998) and prolificacy in ewes, possibly from reduced embryo mortality (Masters \& Fels, 1980). These results show that mineral supplementation both by oral administration and by injection is effective to improve the ewe's reproductive performance. However, zinc supplementation by injection has been reported to be a more effective way to restore zinc blood concentrations in deficient animals than by oral administration (Lamand et al., 1983). A high zinc blood concentration is reached after three days of mineral injection (Lamand, 1978) and it remains elevated for up to 28 days (Lamand et al., 1980). Therefore, it is suggested that supplementation by injection ensures a good supply of trace minerals to achieve optimum reproductive performance (Stokes et al., 2017).

The effect of subcutaneous injection of zinc oxide on the means of the largest preovulatory follicle diameter, measured in the different experimental groups, is shown in Table 1. In general, the effect of the treatment, block and their interaction were not significant $(p>0.05)$. The latter is contradictory to published results in cows, where it was observed that the diameter of the preovulatory follicle increased with the injection of $400 \mathrm{mg}$ of zinc oxide (Anchordoquy et al., 2019). This contradiction can be due to the day when the zinc oxide injection was applied, since in the case of the study in cows by Anchordoquy et al., supplementation was carried out at the beginning of the estrus synchronization protocol, which exposed the animal organism to the effects of zinc for a longer time. It is suggested that the zinc function at the follicular level is directed more to the oocyte (Ménézo et al., 2011), which is particular sensitive to zinc deficiency during the last stages of maturation (Tian \& Diaz, 2012). Delayed development of embryos and pregnancy loss have been observed when zinc dietary deficiencies are created four to five days before ovulation (Tian et al., 2014). This agrees with the fact that intrafollicular zinc concentrations increase as the follicle's size increases (Kor et al., 2013).

Table 1. Diameter of the largest preovulatory follicle $(\mathrm{mm}$, mean $\pm \mathrm{EE})$ in ewes injected with 0 (Control), 100 (z-100) and 200 (z-200) mg of zinc oxide in five farms (F1-5).

\begin{tabular}{c|c} 
Group & $\begin{array}{c}\text { Preovulatory follicle } \\
\text { diameter }\end{array}$ \\
\hline Control & $6.66 \pm 0.23$ \\
\hline z-100 & $6.24 \pm 0.23$ \\
\hline z-200 & $6.14 \pm 0.23$ \\
\hline Block \\
\hline \multicolumn{2}{c|}{ F1 } \\
\hline F2 & $6.56 \pm 0.30$ \\
\hline F3 & $6.00 \pm 0.30$ \\
\hline F4 & $6.46 \pm 0.30$ \\
\hline F5 & $6.26 \pm 0.30$ \\
\hline
\end{tabular}

Means with different superscript letter are significantly different $(\mathrm{p} \leq 0.05)$ 
Mineral supplementation was not part of the feeding program for ewes in any of the farms in the present study. Therefore, there was speculation that sheep had zinc deficiency and that a positive effect from zinc supplementation could impact follicular size, oocyte quality, and pregnancy rate. This study is limited regarding the unknown mineral balance of the ewes before and after zinc injection. In addition, oocyte quality was not evaluated, but pregnancy rate results and the available scientific evidence allow speculating about the results from this study.

The effect of zinc injection on the pregnancy rate in ewes is depicted in Figure 1. In general, no dependency was observed between zinc injection and pregnancy rate $(p>0.05)$, which is similar to the results found in ewes supplemented orally with 50-150 ppm of zinc oxide (Monem \& El-Shahat, 2011). This is contrary to the results reported in cows (Anchordoquy et al., 2019) and goats (Kundu et al., 2014), where an increase in pregnancy rate was observed by injecting $400 \mathrm{mg}$ of zinc sulfate or by oral administration of 100 ppm of zinc oxide to goats.

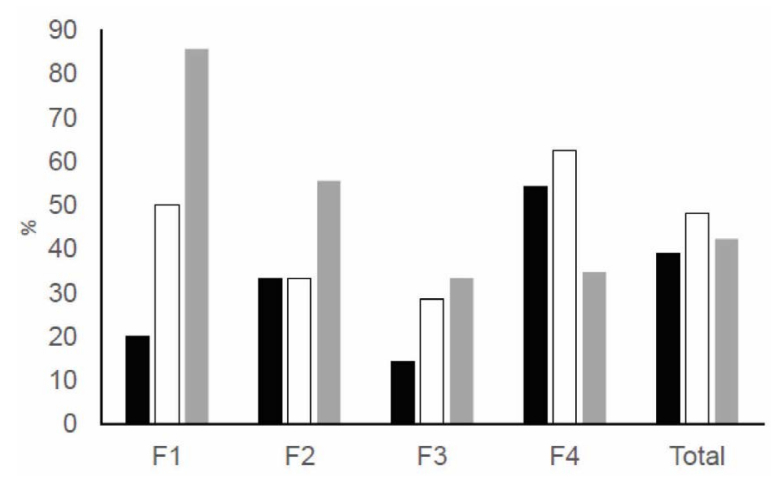

Figure 1. Pregnancy rate of ewes injected with 0 (black bars), 100 (white bars) and 200 (gray bars) mg of zinc oxide on four farms (F1-4).

The beneficial effect of zinc supplementation on pregnancy rate is sustained, at least partly, on the blood concentrations of this mineral being higher in pregnant females than in empty ones (Nazari et al., 2019). In addition, zinc supplementation in laboratory conditions reduces the fragmentation of genetic material in the oocyte (Abdel-Halim et al., 2018), increasing the number of oocytes that reach the blastocyst stage and their quality (Choi et al., 2016; Jeon et al., 2014). In this regard, zinc supplementation to the culture medium increases the size of the embryo inner cell mass, which might be associated to a higher pregnancy rate in cows (Wooldridge et al., 2019). On the other hand, supplementing bulls (Kumar et al., 2006) and adding this mineral to the fertilization medium improves sperm activity and quality (Galarza et al., 2020), which suggests that the fertilization process could be improved under in vivo conditions.

The lack of statical significant differences between experimental groups in pregnancy rates overrides the beneficial effect of zinc on female reproductive performance. However, it can be suggested that the lack of significant difference between treatments could be due to the small sample size in some sheep farms, such 
as F1 and F2. In addition, it has been suggested that the intrinsic characteristics of each farm, such as the initial mineral balance of the animals, affects differently the pregnancy rate in response to the zing levels supplemented, since the low levels of pregnancy are only observed in females with a zinc status considered as deficient, but not in those with a marginal or adequate zinc status (Galarza et al., 2020).

\section{CONCLUSIONS}

The subcutaneous injection of 100 or $200 \mathrm{mg}$ of zinc oxide during an estrus synchronization protocol did not affect the diameter of the largest preovulatory follicle or the pregnancy rate in ewes. It is advisable to perform mineral supplementation according to the female's mineral status.

\section{ACKNOWLEDGEMENTS}

The authors thank the PRODEP program from the Public Education Ministry (Secretaria de Educación Pública, SEP) for the economic support provided to fulfill the present study.

\section{REFERENCES}

sAbdel-Halim, B., Moselhy, W., \& Helmy, N. (2018). Developmental competence of bovine oocytes with increasing concentrations of nano-copper and nano-zinc particles during in vitro maturation. Asian Pacific Journal of Reproduction, 7(4), 161-166p.

Anchordoquy, J.M., Anchordoquy, J.P., Galarza, E.M., Farnetano, N.A., Giuliodori, M.J., Nikoloff, N., Fazzio, L.E., \& Furnus, C.C. (2019). Parenteral zinc supplementation increases pregnancy rates in beef cows. Biological Trace Element Research, 192(2), 175-182p.

Ali H.A., Ezzo, O.H., \& El-Ekhnawy, K.E. (1998). Effect of zinc supplementation on reproductive performance of Barki ewes under practical field condition. Veterinary Medical Journal Giza, 46 (1), 77-87p.

Awawdeh, M.S., Eljarah, A.H., \& Ababneh, M.M. (2019). Multiple injections of vitamin E and selenium improved the reproductive performance of estrus-synchronized Awassi ewes. Tropical Animal Health and Production, 51(6), 1421-1426p.

Choi, Y.H., Gibbons, J.R., Canesin, H.S., \& Hinrichs, K. (2016). Effect of medium variations (zinc supplementation during oocyte maturation, perifertilization $\mathrm{pH}$, and embryo culture protein source) on equine embryo development after intracytoplasmic sperm injection. Theriogenology, 86(7), 1782-1788p.

Delgadillo, J.A., \& Martin, G.B. (2015). Alternative methods for control of reproduction in small ruminants: A focus on the needs of grazing industries. Animal Frontiers, 5(1), 57-65p.

Galarza, E.M., Lizarraga, R.M., Anchordoquy, J.P., Farnetano, N.A., Furnus, C.C., Fazzio, L.E., \& Anchordoquy, J.M. (2020). Zinc supplementation within the reference ranges for zinc status in cattle improves sperm quality without modifying in vitro fertilization performance. Animal Reproduction Science, 221, 106595.

Garcia, E. (1988). Modificaciones del sistema de clasificación climática de Köppen (4. ${ }^{a}$ ed.). Editorial Universidad Nacional Autónoma de México.

Gifford, J.A.H., \& Gifford, C.A. (2013). Role of reproductive biotechnologies in enhancing food security and sustainability. Animal Frontiers, 3(3), 14-19p.

Hill, G.M., \& Shannon, M.C. (2019). Copper and zinc nutritional issues for agricultural animal production. Biological Trace Element Research, 188(1), 148-159p.

Jeon, Y., Yoon, J.D., Cai, L., Hwang, S.U., Kim, E., Zheng, Z., Lee, E., Kim, D.Y., \& Hyun, S.H. (2014). Supplementation of zinc on oocyte in vitro maturation improves preimplatation embryonic development in pigs. Theriogenology, 82(6), 866-874p. 
Kor, N.M., Khanghah, K.M., \& Veisi, A. (2013). Follicular fluid concentrations of biochemical metabolites and trace minerals in relation to ovarian follicle size in dairy cows. Annual Research \& Review Biology 3(4), 397-404p.

Kumar, N., Verma, R.P., Singh, L.P., Varshney, V.P., \& Dass, R.S. (2006). Effect of different levels and sources of zinc supplementation on quantitative and qualitative semen attributes and serum testosterone level in crossbred cattle (Bos indicus $\times$ Bos taurus) bulls. Reproduction Nutrition Development, 46(6), 663-675p.

Kundu, M.S., De, A.K., Jeyakumar, S., Sunder, J., Kundu, A., \& Sujatha, T. (2014). Effect of zinc supplementation on reproductive performance of Teressa goat. Veterinary World, 7(6), 380-383p.

Lamand, M. (1978). Copper and zinc deficiencies treatment by intramuscular injections in sheep. Annales de Recherches Veterinaires, 9(3), 495-500p.

Lamand, M., Lab, C., Mignon, M., \& Tressol, J.C. (1983). A zinc-deficient diet for ruminants: Diagnosis and treatment of deficiency. Annales de Recherches Veterinaires, 14(3), 211-215p.

Lamand, M., Lab, C., \& Tressol, J. C. (1980). Comparison of the efficiency of zinc injected as metal or oxide for zinc deficiency treatment in sheep. Annales de Recherches Veterinaires, 11(2), 147-149p.

López-Alonso, M. (2012). Trace minerals and livestock: Not too much not too little. ISRN Veterinary Science, 2012, 1-18p.

Martínez-Partida, J., Jiménez-Sánchez, L., Herrera-Haro, J., Valtierra-Pacheco, E., Sánchez-López, E., López-Reyna, M., \& Martínez, J. (2011). Ganadería ovino - caprina en el marco del programa de desarrollo rural en Baja California. Universidad y Ciencia, 27(3), 331-344p.

Masters, D.G., Chapman, R.E., \& Vaughan, J.D. (1985). Effects of zinc deficiency on the wool growth, skin and wool follicles of pre-ruminant lambs. Australian Journal of Biological Sciences, 38(4), 355-364p.

Masters, D.G., \& Fels, H.E. (1980). Effect of zinc supplementation on the reproductive performance of grazing Merino ewes. Biological Trace Element Research, 2(4), 281-290p.

Ménézo, Y., Pluntz, L., Chouteau, J., Gurgan, T., Demirol, A., Dalleac, A., \& Benkhalifa, M. (2011). Zinc concentrations in serum and follicular fluid during ovarian stimulation and expression of $\mathrm{Zn}^{2+}$ transporters in human oocytes and cumulus cells. Reproductive BioMedicine Online, 22(6), 647-652p.

Mir, S.H., Mani, V., Pal, R.P., Malik, T.A., \& Sharma, H. (2020). Zinc in ruminants: Metabolism and homeostasis. Proceedings of the National Academy of Sciences India Section B - Biological Sciences, 90(1), 9-19p.

Monem, U.M.A., \& El-Shahat, K.H. (2011). Effect of different dietary levels of inorganic zinc oxide on ovarian activities, reproductive performance of egyptian baladi ewes and growth of their lambs. Bulgarian Journal of Veterinary Medicine, 14(2), 116-123p.

Nazari, A., Dirandeh, E., Ansari-Pirsaraei, Z., \& Deldar, H. (2019). Antioxidant levels, copper and zinc concentrations were associated with postpartum luteal activity, pregnancy loss and pregnancy status in Holstein dairy cows. Theriogenology, 133, 97-103p.

Nasiadek, M., Stragierowicz, J., Klimczak, M., \& Kilanowicz, A. (2020). The role of zinc in selected female reproductive system disorders. Nutrients, 12(8), 2464p.

Partida de la Peña, J.A., Ríos Rincón, F.G., Colín, C., Domínguez Vara, I.A., \& Buendía Rodríguez, G. (2017). Caracterización de las canales ovinas producidas en México. Revista Mexicana de Ciencias Pecuarias, 8(3), 269-277p.

Stokes, R.S., Ralph, A.R., Mickna, A.J., Chapple, W.P., Schroeder, A.R., Ireland, F.A., \& Shike, D.W. (2017). Effect of an injectable trace mineral at the initiation of a 14 day CIDR protocol on heifer performance and reproduction. Translational Animal Science, 1(4), 458-466p.

Swain, P.S., Rao, S.B.N., Rajendran, D., Dominic, G., \& Selvaraju, S. (2016). Nano zinc, an alternative to conventional zinc as animal feed supplement: A review. Animal Nutrition, 2(3), 134-141p. 
Tian, X, \& Diaz, F. (2012). Acute dietary zinc deficiency before conception compromises oocyte epigenetic programming and disrupts embryonic development. Develomental Biology, 23(1), 1-7p.

Tian, X, Anthony, K., Neuberger, T., \& Diaz, F.J. (2014). Preconception zinc deficiency disrupts postimplantation fetal and placental development in mice. Biology of Reproduction, 90(4), 1-12p.

Turk, J. (2016). Meeting projected food demands by 2050: Understanding and enhancing the role of grazing ruminants. Journal of Animal Science, 94(6), 53-62p.

Wooldridge, L.K., Nardi, M.E., \& Ealy, A.D. (2019). Zinc supplementation during in vitro embryo culture increases inner cell mass and total cell numbers in bovine blastocysts. Journal of Animal Science, 97(12), 4946-4950. 